\title{
The nature of post-neoliberalism: Building bio-socialism in the Ecuadorian Amazon
}

DOI:

10.1016/j.geoforum.2017.01.014

\section{Document Version}

Accepted author manuscript

Link to publication record in Manchester Research Explorer

\section{Citation for published version (APA):}

Wilson, J., \& Bayón, M. (2017). The nature of post-neoliberalism: Building bio-socialism in the Ecuadorian Amazon. Geoforum, 81, 55-65. https://doi.org/10.1016/j.geoforum.2017.01.014

\section{Published in:}

Geoforum

\section{Citing this paper}

Please note that where the full-text provided on Manchester Research Explorer is the Author Accepted Manuscript or Proof version this may differ from the final Published version. If citing, it is advised that you check and use the publisher's definitive version.

\section{General rights}

Copyright and moral rights for the publications made accessible in the Research Explorer are retained by the authors and/or other copyright owners and it is a condition of accessing publications that users recognise and abide by the legal requirements associated with these rights.

\section{Takedown policy}

If you believe that this document breaches copyright please refer to the University of Manchester's Takedown Procedures [http://man.ac.uk/04Y6Bo] or contact uml.scholarlycommunications@manchester.ac.uk providing relevant details, so we can investigate your claim.

\section{OPEN ACCESS}




\section{The Nature of Post-Neoliberalism: Building Bio-Socialism in the Ecuadorian Amazon}

This paper explores the ideology and materiality of 'bio-socialism', through which the Ecuadorian government is attempting to catalyse a 'post-neoliberal' transition from the 'finite resources' of Amazonian oil reserves to the 'infinite resources' of biodiversity and scientific knowledge. This experiment is embodied in Ikiam, a public university under construction in the Ecuadorian Amazon. Drawing on extensive field research, we argue that, despite its radical intentions, bio-socialism is functioning as a strategy for the real subsumption of nature to capital, which is being operationalized in Ikiam in ways that reproduce the neoliberal knowledge economy. However, the contradictions of this process imply that, in practice, Ikiam is only intensifying established patterns of the formal subsumption of nature, by commodifying the genetic wealth and indigenous knowledge of the Amazon, and legitimating the expansion of the oil and mineral frontiers. The case of bio-socialism demonstrates the paradoxical nature of actually-existing post-neoliberalism, and illustrates the tendency for utopian ideologies to reproduce the material conditions they are seeking to escape.

Keywords: post-neoliberalism; bio-socialism; ideology; subsumption of nature; Ecuador; Amazon

\section{Introduction}

The planetary catastrophe of global capitalism has starkly exposed our collective inability to imagine the radical transformation of "the socio-ecological co-ordinates of everyday life and the production of new socio-natural configurations" (Swyngedouw 2010a: 307). Under such conditions, the critical analysis of actually-existing experiments in the post-neoliberal production of nature becomes an urgent necessity. A rare example of such an experiment is currently underway in Ecuador. In 2006, Rafael Correa Delgado was elected President of Ecuador, following over two decades of neoliberal reforms that had plunged the country into a profound socio-ecological crisis. Correa's manifesto called for a 'Citizens' Revolution' that would halt "the devastating advance of neoliberalism" (Alianza País 2006: 5). In 2008, a new constitution was ratified, in which Ecuador became the first country in the world to recognise 'the rights of nature', in response to the demands of indigenous social movements that had struggled for decades against the social and environmental consequences of the oil industry in the Ecuadorian Amazon (Becker 2012; Radcliffe 2012). These rights have inspired 
the state project of 'bio-socialism', which promises to replace Ecuador's dependence on the 'finite resources' of Amazonian oil reserves with a development model based on the collective ownership of the 'infinite resources' of knowledge and biodiversity (Ramírez 2012; SENPLADES 2009, 2013).

This paper presents a critique of bio-socialism, as a means of assessing the possibilities and limitations of post-neoliberal development, and as an opportunity to explore the relationship between utopian ideologies and material realities under conditions of global capitalism. We approach this task through a detailed study of Ikiam, a public university currently under construction in the Ecuadorian Amazon, which embodies the economic vision of bio-socialism. 'Ikiam' means 'jungle' in the language of the Shuar indigenous nationality, and the main campus is located near the Amazonian city of Tena, on the boundary of Colonso-Chalupas, a 93,000-hectare biosphere reserve that functions as a "living laboratory" for the new university (Correa 2014; El Telégrafo 2014). An inter-disciplinary team of international scientists is researching the potential industrial and pharmaceutical applications of the biodiversity of the Amazon, while training a future generation of scientists to work in Ecuador's nascent biotechnology industry.

Our analysis of Ikiam is based on extensive field research undertaken in Ecuador in 2015, as part of the National Centre of Strategies for the Right to Territory (CENEDET), a research institute funded by the Ecuadorian government and directed by the Marxist human geographer David Harvey. Our unusual position as critical scholars operating within the Ecuadorian state apparatus provided us with a unique possibility to conduct an internal investigation of an avowedly 'post-neoliberal' project, including participatory observation in the planning process, textual analysis of government policy statements and planning documents, and ninety-seven semi-structured interviews and focus groups with politicians, civil servants, academics and impacted communities. ${ }^{1}$ However, our research on Ikiam also contributed to growing tensions between CENEDET and the Ecuadorian

\footnotetext{
${ }^{1}$ Most interviews were conducted in Spanish, while a limited number were conducted in English. We have not identified those that were conducted in English, in order to protect the anonymity of our interviewees. All quotations from interviews in Spanish and from Spanish language texts have been translated by the authors.
} 
government, exacerbated by the dissemination of research findings that were critical of various dimensions of the Citizens' Revolution. While undertaking field research in the politically sensitive region of the El Mirador copper mine (discussed in section four below), the lead researcher on this project was fired without explanation, and CENEDET was closed down soon afterwards. Through the publication of our findings here, we aim to contribute to debates on the nature of post-neoliberalism in ways that unfortunately proved impossible within the confines of the 'post-neoliberal' state itself. $^{2}$

The case of bio-socialism is of particular interest for the study of post-neoliberalism, not only because of the scale of its ambition, and its rapid materialization in the form of Ikiam, but also due to the profoundly contradictory dynamics of this ultimately failed process. As Slavoj Žižek has argued, an ideological formation not only conceals the material realities of capitalism, but also tends to "create what it purports to conceal, its own 'repressed' point of reference" (Žižek 1997: 6). In this paper, we interpret bio-socialism as an ideological formation that has functioned in precisely this way, by simultaneously concealing and promoting a transition from the formal to the real subsumption of nature to capital, understood as a shift from natural resource extraction towards biotechnological interventions that result in "higher yields, shorter turnover times... Nature, in short, is (re)-made to work harder, faster, better" (Boyd et al 2001: 19). Despite being framed in the discourse of post-neoliberalism, we argue that Ikiam has reproduced many of the defining features of the neoliberal knowledge economy, based upon close cooperation between academia and industry in the real subsumption of nature. The ideological complexities of bio-socialism, however, do not end here. In practice, Ikiam is failing to catalyse this disavowed shift towards real subsumption, and is only succeeding in reproducing existing processes of formal subsumption on an expanded scale, by transforming the genetic wealth and indigenous knowledge of the Amazon into fields of monopoly rent extraction, and by legitimating the extension of the oil and mineral frontiers,

\footnotetext{
${ }^{2}$ For further details of the CENEDET experiment, see Wilson 2017. CENEDET produced eight working papers, which can be downloaded at https://cenedet.wordpress.com/publicaciones/working-papers/
} 
in the context of the collapse of the commodities boom, and the exhaustion of the post-neoliberal project.

Ikiam and other spatial embodiments of post-neoliberal ideology have been largely overlooked in critical analyses of the leftist regimes that swept to power across Latin America in the first decade of the new millennium. An extensive literature questions the extent to which these regimes have succeeded in transcending the neoliberal paradigm, acknowledging their achievements in reducing poverty and expanding social programmes, but emphasizing their sustained commitment to exportled development; their continued dependency on mineral and hydrocarbon 'extractivism', and their reproduction of violent processes of accumulation by dispossession (Arsel et al 2016; Burchardt and Dietz 2014; Grugel and Riggirozzi 2012; Gudynas 2012; Kennemore and Weeks 2011; Latorre et al 2015; Macdonald and Ruckert 2009; Rosales 2013; Veltmeyer and Petras 2014). These studies, however, have given less attention to the ways in which "space, power... and contestation are being made and remade through efforts to materialize post-neoliberal ideologies" (Ellwood et al 2016). This has led to calls for more nuanced analyses of "actually-existing post-neoliberalism" (Yates and Bakker 2013: 2), and an emergent literature has now begun to address such questions (Billo 2015; Boelens et al 2015; Kaup 2014; Perreault 2013; Purcell et al 2016; Webber 2014; Wilson and Bayón $2016 a ; 2016 b)$.

This paper aims to contribute to the study of 'actually-existing post-neoliberalism', through an exploration of the entanglement of space, power, and ideology through which an iconic postneoliberal project has been conceived, constructed, and brought to ruin. ${ }^{3}$ By tracing the twists and turns of this convoluted process, we aim to provide a vivid illustration of the ways in which utopian visions are distorted, inverted, and destroyed in the process of their realization. The paper begins

\footnotetext{
${ }^{3}$ The paper also contributes to a growing literature that draws on Slavoj Žižek's critique of ideology in tracing the perplexing irrationalities and paradoxical involutions of contemporary capitalist development (De Vries 2007; Kapoor 2014; Fletcher et al 2014; Swyngedouw 2010a; Wilson 2014; 2016). We also aim to contribute to the literature on the subsumption of nature to capital (Birch et al 2010; Boyd et al 2001; Labban 2014; Pellizzoni 2011; Smith 2007), by drawing attention to the role of ground rent in reproducing established structures of formal subsumption, and tracing the dialectics of formal and real subsumption 'on the ground'.
} 
with an exploration of bio-socialism as an ideological formation, which is based on an explicitly anticapitalist ideology combined with an implicit ideological commitment to a 'neo-structuralist' policy framework, and which functions as a disavowed strategy for the real subsumption of nature to capital. The second section locates Ikiam within this context, arguing that the ideological formation of bio-socialism, the febrile atmosphere of a commodity boom, and the enduring influence of neoliberal common-sense, have all contributed to the production of Ikiam as a 'utopia of spatial form' that houses a reproduction of the neoliberal knowledge economy. The third section argues that, far from catalysing a transition to the real subsumption of nature, Ikiam is only contributing to the formal subsumption of nature, through the exploitation of genetic material and its associated 'ancestral knowledge', and the appropriation of the monopoly rents that can be extracted from these territorially exclusive commodities. The fourth section considers two further Ikiam campuses planned for the oil and mining regions of the Amazon. These campuses have been abandoned in the context of an expansion of primary resource extraction under conditions of economic crisis, through which an economic model based on 'finite resources' is being extended at the expense of the 'infinite resources' of the social and ecological commons. We conclude by reflecting on the paradoxical nature of actually-existing post-neoliberalism, and the tendency for utopian ideologies to reproduce the material conditions that they are seeking to escape.

\section{MAP ABOUT HERE}

\section{Bio-socialism as an ideological formation}

In order to understand the ideological formation of bio-socialism, it is necessary to begin with the material dynamics of formal and real subsumption that this ideology is structured to disavow, and the historical context in which it has emerged. According to Marx, nature is not productive of value, which solely exists in capitalist society as a measure of socially-necessary labour time. Capitalism emerges with the formal subsumption of labour to capital, understood as the subordination of preexisting forms of production under the reign of wage labour. Inter-capitalist competition, however, 
drives towards the real subsumption of labour, through which the labour process is transformed by technologies that increase productivity and the rate of surplus value extraction (Marx 1976: 10191038). Like labour, nature is formally subsumed to the extent that it is directly exploited in the conditions in which it is found, confronting capital as "an exogenous set of material properties and bio/geophysical processes" (Boyd et al 2001: 3). As such, it provides a source of ground rent for landlords and national states, whose monopoly control of the natural resources required for commodity production enables them to appropriate a portion of the surplus value extracted through the exploitation of living labour in the global centres of industry (Grinberg and Starosta 2015; Purcell et al 2016). Under conditions of real subsumption, by contrast, 'natural' biological processes are manipulated to increase yields, enhance metabolisms, and intensify industrial productivity (Birch et al 2010). The formal and real subsumption of nature to capital are therefore internally related moments within the uneven geographical development of global capitalism.

Prior to the Citizens' Revolution, the Ecuadorian Amazon had been historically incorporated into world markets on the basis of the formal subsumption of nature and the appropriation of ground rent. Since its colonial discovery, the Amazon has been framed in the capitalist imaginary as a land of superabundant natural wealth (Wylie 2014). In 1541, the Spanish conquistador Gonzalo Pizarro set out from what is now the Ecuadorian capital of Quito, descending from the Andes to the Amazon in search of the Land of Cinnamon and El Dorado - mythical cornucopias that were said to be filled with unimaginable quantities of spices and gold (Smith 1990). In the nineteenth century, the rubber boom launched a second wave of colonization of the Ecuadorian Amazon in search of "elastic gold", leading to the enslavement and displacement of the indigenous population (Russotto 2013: 133). In 1967, extensive oil deposits were discovered in the northern Ecuadorian Amazon. As Michael Watts observes, "El Dorado had been located, and it was in an oil well" (Watts 1994: 203).

The first oil concessions were owned and operated by the Texaco-Gulf consortium, which built roads and pipelines that opened the northern Amazon to a rapid process of colonization from the 
highlands, resulting in widespread deforestation and the dispossession of the indigenous peoples of the region. Further socio-ecological impacts included frequent oil spills, the burning of millions of cubic feet of gas and waste oil, and the discharging of billions of gallons of highly toxic formation waters into the rivers of the region, resulting in the poisoning of entire ecosystems and high rates of cancers and other diseases in the local population (Kimerling 1991; Sawyer 2002). By the time of the collapse of the oil price in the early 1980s, and the subsequent neoliberalization of the economy, Ecuador was an "oil nation", in which oil rents consistently accounted for at least 50 percent of export earnings and as much as two-thirds of the national budget (Watts 1994: 200; Perreault and Valdivia 2010). Meanwhile the indigenous nationalities and peasant organizations of the Amazon developed a network of social movements to defend their communities against transnational oil companies. Many of these organizations became involved in the national indigenous movement, and contributed to a series of popular uprisings that brought the neoliberal model into crisis, and that opened the space for the election of Rafael Correa in 2006, on a post-neoliberal platform that promised a new relationship with nature (Becker 2011, 2013a).

The 2008 constitution was framed around the Kichwa indigenous concept of sumak kawsay, (Buen Vivir or 'Good Living'), which was understood to imply "an economic development model that is in harmony with nature" (Arsel 2012: 157). As already mentioned, the constitution was the first in the world to codify the rights of nature, with Article 71 stating that "Nature, or Pachamama... has the right to integral respect for its existence, and for the maintenance and regeneration of its life cycles, structures, functions and processes" (Asemblea Consituyente 2008: 11). However, in the words of René Ramírez Gallegos, the intellectual author of bio-socialism, while the constitution established the "principles, objectives, and goals" of the Citizens' Revolution, it had little to say on "the factors of accumulation for the construction of a different type of economy" (Ramírez 2015a). As Secretary of the newly created National Secretariat of Planning and Development (SENPLADES), Ramírez was charged with the formulation of this new accumulation strategy (Ramírez 2015a). It was in this context that he set out his vision for bio-socialism as "the materialization and radicalization of... the 
Citizens' Revolution" (SENPLADES 2009: 5). In his words, "the construction of... the society of Buen Vivir" must be guided by "great ethical, theoretical and utopian orientations", which he defined as "the socialism of sumak kawsay, or republican bio-socialism" (Ramírez 2015b: 36-37). This new vision sought not to "take better advantage of capitalism but to transform... the capitalist mode of accumulation" (Ramírez 2015a). Ramírez was clear that the new constitution "cannot coexist with an economic strategy of primary resource exportation" (Ramírez 2012: 38). To this end, he proposed "a new bio-strategy of accumulation", based upon a transition from the "finite resources" of oil and other primary commodities to the "infinite resources" of "bioknowledge" (bioconocimiento), understood as the application of scientific knowledge to the immeasurable biodiversity of the Ecuadorian Amazon in the production of collectively owned public goods (Ramírez 2012: 8; 2015b). Underlying this overtly utopian and explicitly anti-capitalist discourse, however, was a more implicit commitment to 'neo-structuralism', a policy framework developed in the 1990s by the Economic and Social Commission for Latin America and the Caribbean (ECLAC). In the 1960s and 1970s, ECLAC promoted the 'core-periphery' theory of international inequality, and the corresponding development model of Import-Substitution Industrialization (ISI), which was implemented across Latin America. Following the debt-crisis of the 1980 s and the rise of neoliberal hegemony, ECLAC abandoned the core-periphery model and replaced ISI with the more 'pragmatic' post-neoliberal agenda of neo-structuralism (Rival et al 2015). In contrast to the 'spurious competitiveness' of Latin American neoliberalism, based on cheap labour and natural resource exploitation, neo-structuralism advocated a state-led shift to 'systemic competitiveness' based on technological innovations, productivity gains, and 'an intelligent insertion into international markets' (Leiva 2008a, 2008b). Central to this strategy was the promotion of "knowledge-intensive sectors", which would drive the transformation of "the productive matrix" (ECLAC 2012: 16-18).

As Fernando Leiva has argued, in his comprehensive critique of neo-structuralism, the endorsement of competitiveness and export-led development did not mark a radical break with neoliberal 
orthodoxy, but constituted "the political-economic consolidation, legitimation and furtherance of the process of capitalist restructuring initially set in motion by neoliberal ideas and policies" (Leiva 2008a: xxvii). This helps to explain the limited ambitions of post-neoliberal projects in countries such as Chile, Brazil and Uruguay, where neo-structuralism was the dominant policy doctrine. Analyses of post-neoliberalism in Latin America tend to distinguish between these regimes and more radical experiments in Bolivia and Venezuela, with Ecuador invariably grouped with the latter (see for example Castañeda 2006; Burbach et al 2013; Ellner 2012). The anti-capitalist discourse of biosocialism encourages this classification, and Leiva himself has praised the Citizens' Revolution an alternative to neo-structuralist orthodoxy (Leiva 2008a: 217). Yet when interviewed, politicians including Ramírez identified neo-structuralism as the common-sense ideology of the Citizens' Revolution, which was promoted by the cohort of academic economists who formulated the original manifesto, and whose intellectual background was in heterodox economics as opposed to Marxist theory. ${ }^{4}$ This cohort was led by Rafael Correa, himself a neo-structuralist economist who published a working paper with ECLAC prior to entering politics (Correa 2002). Confronted with the urgent need to formulate a viable accumulation strategy, Ramírez and his team at SENPLADES seized upon neostructuralism as a ready-made and widely accepted policy framework, and national development plans have since been consistently premised on "systemic productivity and competitiveness... [and] a strategic insertion in the world market" (SENPLADES 2013: 78).

As an ideological formation, bio-socialism is therefore structured on two levels. At the level of immediate appearances, its overtly anti-capitalist discourse constitutes a deliberately articulated "ideological strategy" (Eagleton 2007: 33), which aims to embody the principles of the new constitution, and to respond to the demands of the social movements that brought the Citizens' Revolution to power. But at a deeper level, bio-socialism is informed by neo-structuralism, which

\footnotetext{
${ }^{4}$ This was explained to us by several of the architects of the Citizens' Revolution, including René Ramírez (Interview 11/02/2016, Quito, Ecuador) and Alberto Acosta, president of assembly that drafted the 2008 constitution, and now a prominent critic of the Correa administration (Interview 11/09/2015, Quito).
} 
operates not as a consciously adopted ideological position, but as an unquestioned framework for the interpretation of economic reality and the formulation of policy solutions. Crucially, as Slavoj Žižek has argued, "it is precisely the neutralisation of some features into a spontaneously accepted background that marks out ideology at its purest" (Žižek 2008: 31). In practical policy terms, biosocialism thus came to be formulated, not as a radical anti-capitalist utopia, but as an ostensibly 'pragmatic' neo-structuralist approach to "the transformation of the productive matrix," from one of primary commodity dependency to one based on "technology, innovation, and knowledge" (SENPLADES 2013: 35). This new economy would involve the development of "higher performance crops" and "the genetic modification of organisms" (SENESCYT 2013: 13), and would deploy "biological and genetic information [in the] diversification of national exports, [including] bioprospection, bio-production, and bio-commerce" (SENPLADES 2013: 42).

This planned transition from 'finite' to 'infinite' resources did not signify the transformation of capitalist social relations promised by bio-socialism in its more radical iterations. On the contrary, it implied a disavowed leap from the formal to the real subsumption of nature to capital, "replacing a logic of extraction with one... in which industrial and natural processes become integrated in the pursuit of increased productivity and profitability" (Boyd et al 2001: 18, 24). Paradoxically, this "ecological revolution" (SENPLADES 2013: 69) has been facilitated, rather than obstructed, by the invocation of 'the rights of nature'. Ramírez and other key figures in the Citizens' Revolution have been profoundly influenced by post-development theorists such as Arturo Escobar and Eduardo Gudynas, who reject Marxism on the basis of its allegedly 'productivist' reduction of nature to use values (Gudynas 2011). Ramírez cites these theorists in arguing that Marxian value theory must be replaced by an affirmation of "the ethico-moral value... of life itself" (Ramírez 2015c), and insisting that bio-socialism must transcend the "anthropocentrism" of traditional socialism by "recognising the intrinsic values of nature" (Ramírez 2012: 23). ${ }^{5}$ But as Žižek has argued in his critique of

\footnotetext{
${ }^{5}$ Gudynas has also described bio-socialism as broadly "compatible with the Buen Vivir perspective and the rights of nature" (Gudynas 2011: 446). The mutual admiration between Gudynas and Ramírez is symptomatic
} 
mainstream ecology, "Nature does not exist... as a periodic balanced circuit, thrown off its tracks by man's inadvertence" (Žižek 1992: 38). Instead, as Jason W. Moore points out, "the history of capitalism is one of successive historical natures", in which "capitalism has survived not by destroying nature... but through projects that compel nature... to work harder and harder" (Moore 2015: 19, 13).

The replacement of Marxian value theory with an ethical affirmation of a harmonious external nature thus obscures and facilitates the production of nature by capital. As Ramírez explains, "Ecuador must overcome its role as a provider of primary goods that degrade nature... The new strategy implies the generation of added value by ethically putting life to work... with respect for the rights of nature" (Ramírez 2012: 38, emphasis added). The discourse of 'the rights of nature' therefore functions as a third component of bio-socialism as an ideological formation, by framing the transition from the formal to the real subsumption of nature to capital as a defence of the rights of nature itself. This disavowed promotion of capitalism as the solution to its own pathological symptoms is the defining feature of utopian socialism, understood as "a belief in the possibility of a universality without its symptom, without the point of exception functioning as its internal negation" (Žižek 1989: 23). The remainder of this paper explores the implementation of this utopian ideology in the case of Ikiam, through which its 'internal negations' have been expressed in spatial form.

\section{Paradise of bioknowledge}

Ironically for a project devoted to escaping petroleum dependency, it was the long oil boom of the 2000s that brought the building of bio-socialism within the horizon of material possibility. Once in office, Correa took advantage of the boom to renegotiate oil contracts and strengthen the role of

\footnotetext{
of a peculiar affinity between post-development theory and neo-structuralism. Post-development scholars critique the neo-extractivist practices of Ecuador and other post-neoliberal governments in Latin America (see for example Macias and Alonso 2016). Yet their shared rejection of value theory leads both approaches towards surprisingly similar visions of sustainable development, and to a shared over-estimation of the power of discourse in abstraction from the material dynamics of capital accumulation (Chávez 2016).
} 
the state in the Ecuadorian oil industry (Escribano 2013; Ruiz 2013). ${ }^{6}$ These reforms resulted in a significant increase in state revenues, with which the Citizens' Revolution now promised to "sow the oil and harvest a productive matrix for the knowledge society" (SENPLADES 2013: 15). In 2011, Ramírez was appointed Secretary of another newly created ministry, the National Secretariat of Science, Technology, and Higher Education (SENESCYT), and tasked with overseeing this process. The flagship projects of bio-socialism were announced the following year, when SENESCYT created Yachay, a knowledge city in the highlands devoted to the development of technological industries, and Ikiam, "dedicated to the generation of bioknowledge" (Correa 2014: 25). In Ramírez's words, "It is no longer enough to expound theoretical sophisms... If the utopia of the Right is the construction of fiscal paradises, then the Left must construct paradises of bioknowledge open to Buen Vivir" (Ramírez 2015a).

In setting out his vision for the achievement of bio-socialism, Ramírez was aware of the parallels with the neoliberal knowledge economy. Since the 1980s, university research in the USA and Europe has been increasingly incorporated into processes of capital accumulation, through the development of a 'triple-helix' of integrated relations between academia, industry, and government (Vallas and Kleinman 2008). The biotechnology sector has been a central driver of this process, through which capital asserts increasing influence over academic research agendas, and science departments are increasingly financed and judged in terms of the quantity of capital accessed and the number of patents acquired (Zucker, Darby and Armstrong 2002). As Ramírez himself has acknowledged, "Bioknowledge, at this moment... is the mainstream of capitalism, and what is at stake is the construction of a different kind of bioknowledge" (Ramírez 2015a). When we visited Ikiam in November 2015, however, we found that the university was reproducing precisely the neoliberal knowledge economy that Ramírez had intended to avoid. Ikiam was inaugurated in October 2014,

\footnotetext{
${ }^{6}$ In 2007 Correa imposed a 99 percent windfall tax on oil companies, and the 2010 Hydrocarbons Law increased the government's share in oil revenues from 13 to 87 percent, with companies forced to comply or face expropriation. The resulting resources were channelled into a wide range of public works, raising public investment to 15 percent of GDP - the highest in Latin America (Correa 2014).
} 
and by the end of 2015 the university had assembled an integrated multi-disciplinary team of international scientists devoted to the cataloguing of the biodiversity of the Ecuadorian Amazon, the isolation of potentially marketable active agents, and their patenting and commercialization, under the rubric of an overarching research project entitled Ikiam: Fuente de Vida ('Ikiam: Source of Life'). In the words of one of the organizers of this project, the aim is "to exploit the megadiversity of the Amazon... What we want, essentially, is to study a plant, learn how it is used in the [indigenous] community, test its active ingredient and isolate this type of drug in distinct cellular models". ${ }^{7}$ The resulting products are to be marketed by the Centre for Entrepreneurship, which is devoted to "the commercialization of patents... Each time that the researcher has found a new method of extracting a component... we [will] help them to start the process of getting a patent" ${ }^{8}$

The explanation for this reproduction of the neoliberal knowledge economy lies in a complex intertwining of ideological and material factors. In the first place, as discussed in the previous section, beneath its radical anti-capitalist discourse, bio-socialism is underpinned by the neostructuralist policy framework of systemic competitiveness, which is broadly consistent with neoliberal fundamentals. Neo-structuralism's model of best practice is the rapid state-led industrialization achieved by South Korea and the other 'Asian Tigers' (Leiva 2008a: 90-98). Correa was impressed by a visit to South Korea in 2010, and insisted that Ikiam and Yachay should be modelled on South Korean knowledge cities, despite the fact that Ramírez had identified this model with the "cognitive capitalism" that bio-socialism was intended to contest. ${ }^{9}$ Correa's decision to follow the South Korean model also contradicted the advice of the Nobel Prize-winning environmental scientist Arturo Villavicencio, who was serving as a consultant to Correa at the time. Villavicencio emphasized that the South Korean knowledge economy was the outcome of a longterm process of industrialization, and was driven by Korean-based multinational corporations,

\footnotetext{
${ }^{7}$ Ikiam scientist \#1. Interview 04/11/2015, Ikiam, Ecuador.

8 Ikiam scientist \#2. Interview 07/11/2015, Ikiam.

${ }^{9}$ René Ramírez. Interview 11/02/2016, Quito.
} 
whereas Ecuador lacked the industry, capital, and personnel required for such a project. According to Villavicencio, Correa dismissed these arguments, insisting on the necessity of "thinking big, leaping forward... He didn't understand that you can't simply jump over these processes."10

The inapplicability of the South Korean development model to the Ecuadorian context, however, is more complex than Villavicencio suggests. As Grinberg and Starosta (2009) have argued, the failure of industrialization in South America in comparison to the success of the 'Asian Tigers' is primarily due, not to differences in the planning process, but rather to the centrality of ground rent to Latin American capital accumulation, which has historically protected industrial capital from full exposure to the global law of value, leading to a progressive loss of world market competitiveness over time. Indeed, inadequate planning can itself be interpreted as an expression of this deeper economic structure. Correa's insistence on the possibility of radical and immediate transformation was symptomatic of "the time of oil" (Larkin 2013: 334) - the sudden explosion and unpredictable longevity of the oil rents upon which the transformation of the productive matrix depended. The pressure of this febrile temporality has led in turn to a lack of adequate planning. In the words of Carlos Ávila, rector of Ikiam from 2014 to 2016, "We are attempting to create an economy of science, technology and innovation... without having a solid basis in planning... We are trying to solve... structural problems without being clear what those problems are."11 This opinion is shared by Villavicencio, who has pointed out that "there is no official document that coherently defines the objectives, strategies and priorities in the fields of science and technology" (Villavicencio 2014: 16). In the absence of a strategy for the materialization of bio-socialism, Ikiam has been colonized by the neoliberal common-sense of the mainstream international scientific academy. When asked about bio-socialism, Ávila explained that "For me, socialism is not the best alternative... because as soon as we are talking about bioknowledge we are talking about industry... and that industry can be

\footnotetext{
${ }^{10}$ Arturo Villavicencio, Professor of Environmental Sciences at the University of the Andes and member of the Intergovernmental Panel on Climate Change (IPCC) that was awarded the Nobel Prize in 2007 (Interview 25/11/2015, Quito).

${ }^{11}$ Carlos Ávila, Rector of Ikiam 2014-2016. Interview 23/10/2015, Quito.
} 
undertaken by private enterprise." ${ }^{12}$ One Ikiam scientist emphasized that to compete in the international biotechnology sector, "you have to be in the business" (this last word was spoken in English).${ }^{13}$ Another stressed the importance of "cooperation between public institutes and private companies,"14 while a third argued that Ikiam must "embrace commercialization strategies."15

In this context, Ikiam functions as what David Harvey (2000: 104-113) would call a "utopia of spatial form", which inscribes a utopian ideology into a spatial structure, while facilitating the reproduction of hegemonic social relations within that structure. The first architectural plan for Ikiam was designed by a South Korean consultancy, in the brash and ostentatious style of an East Asian knowledge city. This plan, however, was rejected in favour of a design more consistent with the explicit ideological orientation of 'the socialism of sumak kawsay'. ${ }^{16} \mathrm{~A}$ new competition was launched, entitled 'Wild Architecture'. The winners of the first round emphasized harmony with the ecology of the region, including laboratories constructed in the shape of leaves, and "bridges that change direction organically, evoking the structures of trees" (El Comercio 2014a; 2014b). The selected design was based on the vernacular architecture of the Huaorani indigenous nationality, and was conceived as "a hybrid that reinterprets... the millennial knowledge of this incredible culture." ${ }^{17}$ The post-neoliberal ideology of 'the rights of nature' was thus embodied in a spatial form designed to contain a distinctly neoliberal strategy for the real subsumption of nature to capital. Such utopias of spatial form are symptomatic of the 'revolutionary' projects that have historically accompanied the inflation of national budgets during commodity booms. As Fernando Coronil has argued, in his analysis of the 'Great Venezuela' project financed by the oil boom of the 1970s, commodity booms transform "State representatives, the visible embodiments of the invisible powers of oil money, [into] powerful magicians who pull social reality... out of a hat" (Coronil 1997:

\footnotetext{
${ }^{12}$ Carlos Ávila. Interview 23/10/2015, Quito.

13 Ikiam scientist \#3. Interview 06/11/2015, Ikiam.

${ }^{14}$ Ikiam scientist \#1. Interview 04/11/2015, Ikiam.

15 Ikiam scientist \#2. Interview 07/11/2015, Ikiam.

${ }^{16}$ Member of the Ikiam architectural team \#1. Interview 29/05/2015, Quito.

${ }^{17}$ Member of the Ikiam architectural team \#2. Interview 18/08/2015, Quito.
} 
2). The 1970 s oil boom also triggered the 'White Revolution' in Iran, where the Shah "claimed to have suddenly been blessed with a shining vision [of] 'Prosperity for All'”' (Kapuscinski 2006: 53), and launched the accelerated industrialization of Nigeria, while ensuring that "the magical realism of Nigerian modernity... was instant, effortless, and above all spectacular" (Apter 2005: 41-42). In each of these cases, the euphoria of the boom inspired the feverish construction of iconic spatial utopias that were temporarily suspended on a fountain of ground rent, but were then exposed as 'white elephants' once the flood of rents receded (Bridge and Le Billon 2010; Watts 1994). The next section reveals Ikiam as a white elephant of this kind, which has failed to catalyse the real subsumption of nature to capital, or even to produce the utopian spatial form in which this strategy was to be concealed. ${ }^{18}$

\section{Science fiction}

By the time of the launch of Ikiam in October 2014, the 'time of oil' had begun to impose itself on the Citizens' Revolution. The oil price had started to collapse from its highpoint of US\$115 per barrel a few months earlier, and the budget for Ikiam was reduced several times over the course of 2015, as petroleum prices continued their precipitous decline. ${ }^{19}$ As a consequence, the ecological utopia envisioned by the architects has yet to be constructed. As of January 2017, the university continues

\footnotetext{
${ }^{18} \mathrm{lkiam}$ 's partner institution, Yachay, is another utopia of spatial form containing an even more overtly neoliberal accumulation strategy. Like Ikiam, Yachay was designed in collaboration with South Korean consultants, and is based on the model of the East Asian free trade zone (Macias and Alonso 2016; Purcell et al 2016). The aim is to attract multinational pharmaceutical and biotechnology corporations to locate their research and development facilities in Yachay. A glossy brochure written in English promises foreign investors a "competitive environment", based on "the best incentives in the region", including "credit for investment"; "reduction of taxes for company investors"; "co-financing for human talent development in the private sector"; and "a customs destination with unique financial, tax and commerce alternatives", including a 5 percent reduction in Corporate Income Tax, and tax exemptions on international financial transactions and the importation of capital goods and raw materials (SENESCYT 2013). Like Ikiam, Yachay's name has been taken from the language of one of Ecuador's indigenous nationalities, meaning 'knowledge' in Kichwa. As one of our anonymous reviewers noted, "yachay embodies the dynamic nature of knowledge, knowledge production, and the realization of knowledge-as-practice" (see also Howard 2002). Yet rather than engaging with yachay as the basis for a 'bioknowledge' consistent with the 'socialism of sumak kawsay', the Correa administration has merely appropriated the word 'yachay' for the branding of a neoliberal 'knowledge city'.

${ }^{19}$ The Ecuadorian government originally planned to invest US\$400 million in the construction of Ikiam (EI Comercio 2012a). Several people involved in the planning and management of Ikiam told us severe cuts had been made to the Ikiam budget during 2015, although precise figures are not publically available.
} 
to be housed in the administrative buildings, a set of temporary structures described by a member of a local indigenous community as "a chicken hutch." ${ }^{20}$ The Ikiam scientists therefore lack the stateof-the-art laboratories that they require to advance in their research. Without such facilities, as several of these scientists explained to us, Ikiam is unable to isolate active molecules and identify genetic codes, and will be reduced to producing inventories of plant and animal species with potentially marketable properties. These inventories, furthermore, are unlikely to be developed by nationally-based industries, for the simple reason that no such industries exist. The CEO of a small Ecuadorian biotech start-up told us that "a business needs three things to be successful: technology, market, and investment", and went on to explain that none of these factors are present in Ecuador: a coherent national plan for the biotechnology sector "does not exist"; there is "no commercial structure to exploit the biodiversity"; and Ecuador's oligopolistic bourgeoisie is more concerned with "drowning" potential competition that investing in national development. ${ }^{21}$ As the rector of Ikiam ruefully observed, Ecuador aspires to be a world leader in the highly competitive biotechnology sector, "but we don't even have the capacity to produce our own toilet paper". ${ }^{22}$

In the absence of adequate laboratories to research and develop its discoveries, and without a national biotechnology sector to bring these products to market, Ikiam will be obliged to export the genetic wealth of the Amazon for development by foreign research institutes and corporations. In the words of one of the project leaders of Ikiam: Fuente de Vida, "If we don't invest properly... if we cannot advance beyond producing an inventory... then that inventory will go [abroad], because it's a very competitive area". ${ }^{23}$ An economist who has worked as a consultant on the transformation of the productive matrix made a similar point, arguing that "You need an industrial base in your country that can use all this knowledge that you are generating... otherwise it will just fly to other

\footnotetext{
${ }^{20}$ Resident of Alto Tena, a community near Ikiam. Focus group 08/11/2015, Alto Tena, Ecuador.

${ }^{21}$ CEO of biotechnology start-up company. Interview 08/10/2015. Ibarra, Ecuador.

${ }^{22}$ Carlos Ávila. Interview 23/10/2015, Quito. The majority of toilet paper consumed in Ecuador is imported, and the few Ecuadorian factories producing toilet paper do so with imported materials (El Comercio 2014C).

${ }^{23}$ Ikiam scientist \#1. Interview 04/11/2015, Ikiam.
} 
countries... In the end you are just making cheaper research for other people elsewhere, who are going to exploit all these results. ${ }^{24}$ In other words, a strategy for the real subsumption of nature to capital through the patenting of genetic sequences and the development of biotechnological commodities is in danger of being reduced to a further iteration of the formal subsumption of nature on which the Ecuadorian economy has traditionally been based, with Ikiam extracting primary resources in their raw state in the form of flora and fauna samples, and exporting them for development and incorporation into processes of real subsumption underway elsewhere.

The appropriation of "ancestral knowledge" (Ikiam 2016: 6) is central to this process of formal subsumption. ${ }^{25}$ As one of the Ikiam scientists explained, in the absence of laboratories, the research team is entirely dependent on the knowledge of indigenous shamans and herbalists, "so this means we need researchers who have knowledge of cultural anthropology, of ethnology, of linguistics, because we have to speak to the indigenous people".$^{26}$ This point was reinforced by another scientist, who emphasised that "Ancestral knowledge is a great advantage for us. It's something that they don't have [access to in competing research centres]." ${ }^{27}$ This scientist explained that the research team at Ikiam had already constructed "an extensive database, because they've developed contacts with the communities, they've inventoried certain species... and [now] they need to pursue international collaborations for their development" ${ }^{28}$ Representatives of the indigenous communities surrounding Ikiam were critical of these practises. A member of the local parish council suggested that Ikiam "could take the knowledge that a plant could cure a disease [and use it] to create huge botanical gardens to process [the resulting product]. But they have not provided our

\footnotetext{
${ }^{24}$ Government consultant working on the productive matrix. Interview 07/10/2015, Quito.

25 The discourse of 'ancestral knowledge' adopted by the Correa administration reproduces colonial relations of power-knowledge, by reducing the dynamic knowledges of diverse indigenous nationalities to fetishized objects of a static past. (Thanks to one of the anonymous reviewers for encouraging us to draw attention to the problematic nature of this terminology).

${ }^{26}$ Ikiam scientist \#2. Interview 07/11/2015, Ikiam.

27 Ikiam scientist \#1. Interview 04/11/2015, Ikiam.

28 Ikiam scientist \#1. Interview 04/11/2015, Ikiam.
} 
people with that support. They just come from outside and take away our knowledge" ${ }^{29} \mathrm{~A}$ leader of one of the communities collaborating with Ikiam described the situation as follows:

I've participated in the university's investigations and I've noticed that all their research concerns the natural, biological aspects of our plants. They are compiling information on the ways in which our elderly people use medicinal plants. Their research is not going to benefit us. They are obliging us to get all the information from our grandparents on the medicinal uses of all the plants that exist. They are going to process it at the scientific level, and our knowledge that has been generated for generations is going to be useless to us. How are we going to benefit from it?"30

In response to these concerns, Ikiam organized a two-day workshop in November 2015, to which it invited representatives of several indigenous nationalities, with the aim of producing a 'Code of Ethics' to govern the conditions under which research would be conducted. ${ }^{31}$ In practice, the event was focused on the negotiation of a pay scale for the provision of services to the researchers by members of the indigenous communities. Hourly and daily rates were discussed for a predetermined list of services that included manual labour such as trail cutting alongside the provision of specialist knowledge. This practice contradicted the position of indigenous social movements across Latin America, who assert that the collective dimension of their knowledge precludes its patenting and commodification (Brush 1993). This point was made by a Kichwa participant, who observed that "What we are doing is negotiating, commercializing... suggesting numbers", whereas "The criteria for [calculating] the benefits of traditional knowledge, given that it is collective, should be other considerations... I'm not sure it can be done in percentages... I don't think so." 32 One of the event organizers, however, quickly responded: "Well I do think so... It's not perfect, but it allows us to deepen our analysis to arrive at a real valuation." ${ }^{33}$ This common-sense neoliberal perspective

\footnotetext{
${ }^{29}$ Member of the parish council of Muyuna. Interview 06/11/2015, Muyuna, Ecuador.

${ }^{30}$ Resident of Atacapi, a community across the river from Ikiam. Focus group 07/11/2015, Atacapi, Ecuador.

${ }^{31}$ As members of CENEDET, the authors were invited to participate in the Code of Ethics workshop, and attended the entire event.

${ }^{32}$ Workshop participant. Ikiam Code of Ethics Workshop, 26/11/2015.

${ }^{33}$ Workshop organizer \#1. Ikiam Code of Ethics Workshop, 26/11/2015.
} 
was shared by the great majority of workshop participants, most of whom enthusiastically engaged in the negotiation of the pay scale. This was no coincidence, as representatives of the indigenous nationalities had been carefully selected, with friends and trusted associates of the organizers given priority. Members of radical social movements, on the other hand, had been deliberately excluded, and had reacted angrily to their exclusion, as another of the organizers later explained:

\footnotetext{
“We've got a lot of the [indigenous] politicos mad at us! Because... we decided that we wanted... really pragmatic advice. We wanted people - 'ok, you've worked with an anthropologist, you've worked with a linguist. What do you think it's worth? What do you think they should pay you?' We wanted that kind of pragmatic stuff that you can't get from people who haven't done it. We also wanted people that weren't radically political... We didn't want a bunch of political speeches about 'You're exploiting us'... So we invited people who we know are thoughtful, that we know can see both sides of the situation." ${ }^{34}$
}

In his reflections on the construction of bio-socialism, René Ramírez has warned that without a genuine "connection with the collective", Ikiam and other flagship projects of the Citizens' Revolution will "merely reproduce a socially exclusionary and unjust system" (Ramírez 2015a: 4-5). Rather than pioneering a new form of collective engagement, however, the 'Code of Ethics' workshop embodied what Erik Swyngedouw has identified as the "post-political" modality of neoliberal environmental governance, in which a naturalized market logic predetermines the coordinates of debate "irresponsible' partners are excluded", and antagonisms are disavowed by "displacing conflict and disagreement onto the terrain of consensually manageable problems, expert knowledge, and interest intermediation" (Swyngedouw 2010b: 227, 225). At the workshop, the actors within this depoliticized framework were unconsciously participating in the social construction of a commodity, by agreeing upon the terms and conditions under which knowledge as a collective use value would be extracted and transformed into a scarce resource under private control, as a vehicle for the appropriation of monopoly rents (Zeller 2008 95-97).

${ }^{34}$ Workshop organizer \#2. Interview 03/12/2015, Quito. 
Far from engineering a linear transition from finite to infinite resources, Ikiam is therefore performing the precise reverse of this process: the transformation of infinite resources into finite resources, through the patenting of biodiversity and "the enclosure of socially produced knowledge" (Zeller 2008: 90). This inversion is symptomatic of the fact that the underlying relationship between the formal and real subsumption of nature is not linear, but dialectical (Smith 2007: 18). As Jason W. Moore (2011: 131) has argued, "capitalism's ever-accelerating transformation of biophysical natures" is inescapably related to "its voracious appetite for new frontiers of appropriation". In Ikiam, a strategy for the accelerating transformation of the biodiversity of the Amazon has become entangled in this dialectical relation, and is only succeeding in transforming biodiversity itself into a new frontier of primary resource extraction, while 'ancestral knowledge' is reduced to a field of rentier capitalism, established through processes of commodification and accumulation by dispossession (Harvey 2014: 251). The final section of this paper explores a further dimension of this conundrum, in which the 'infinite resources' of knowledge and biodiversity are being subordinated to the 'finite resources' of copper and oil, through the intensified reproduction of Ecuador's established location as a natural resource exporter within "the global ecological fix, with its constitutive dialectic of productivity and plunder" (Moore 2011: 133).

\section{The limits of infinity}

Ikiam was originally designed to include two secondary campuses. One was to be located in El Eno, amidst the oil fields of Sucumbios in the northern Ecuadorian Amazon, while the other was planned for the mining centre of El Pangui, in the province of Zamora-Chinchipe, near the southern border with Peru. In contrast to the main campus's focus on biotechnology, these secondary campuses were to specialize in petrochemicals and metallurgy, in order to provide the qualified personnel required for their local industries (EI Comercio 2012b). By the time these campuses were announced in October 2012, the Correa administration had abandoned its initial opposition to the oil and mining sectors, and was engaged in the aggressive expansion of the primary resource frontier, even as it 
continued to deploy the discourse of "the socialism of Buen Vivir" (SENPLADES 2013). During his time in office, Correa's legitimacy had become increasingly dependent on the maintenance of high levels of public investment, which were sustaining a broad-based consumption boom. In lieu of the transformation of the productive matrix, this investment continued to be heavily dependent on oil revenues. Furthermore, following its exclusion from international credit markets in 2008 , after partially defaulting on its debts, the Correa administration had signed several 'debt-for-oil' contracts with China, which provided added urgency to the expansion of oil production. From 2009 onwards, the government opened a series of bidding rounds for the concession of new oil blocks, many of which were located in socially and environmentally sensitive areas, while signing contracts with foreign multinationals for the joint exploitation of Ecuador's mature reserves (Escribano 2013; Iturralde 2013). In 2009, in the context of a boom in gold and copper prices, the Correa administration also issued a new mining law, which opened the sector to transnational capital. The law allowed companies to prospect on communally held land without permission, scheduled community consultation after the granting of concessions, and sanctioned the use of force in the event of the obstruction of mining activities by popular resistance (Davidov 2013; Rosales 2013).

The secondary Ikiam campuses were conceived in the context of this newfound commitment to the formal subsumption of nature to capital. In December 2015, however, both these campuses were abandoned, as a consequence of the austerity imposed on the Correa administration by the collapse of the oil price ${ }^{35}$ Meanwhile, the expansion of the oil and mineral frontiers that surround them continues apace. In the case of El Pangui, the abandoned campus has been central to the ideological legitimation of this process, given its proximity to the proposed site of the MIrador copper and gold mine, which is located in the densely forested mountains of the Cordillera del Condor. The Mirador concession is held by Ecuacorriente (ECSA), which is owned by a Chinese consortium. In March 2012,

\footnotetext{
${ }^{35}$ When conducting our field research on Ikiam, we arrived at the sites of each of the two secondary campuses just days after their cancellation. These decisions were explained to us by local government officials, and in both cases were due to the severe reduction in the state budget imposed by the oil crisis.
} 
ECSA signed a US\$1.4 billion contract with the Ecuadorian government for the exploitation of EI Mirador. The opencast mine will be 2.5 kilometres wide and 650 metres deep, involving the removal of 590 million tonnes of rock in the extraction of 2.9 million tonnes of copper ore, as well as the construction of roads, camps, and a tailings reservoir for the storage of millions of litres of toxic waste (ANDES 2012; Escribano 2013; Sacher et al 2015).

The signing of the contract marked the inauguration of large-scale mining in the country, and was met with protests and demonstrations due to the anticipated ecological impact of the mine, and the fact that the proposed site was populated by Shuar and mestizo peasant communities. The site was selected as the symbolic starting point for the national indigenous March for Life, Water and the Dignity of the People, which embarked for the capital city of Quito shortly after the signing of the contract, and which marked a significant moment in the breakdown of the relationship between indigenous social movements and the Citizens' Revolution (Becker 2013b: 58; Iturralde 2013: 173). As part of the contract, however, the Correa administration had secured the forward payment of US\$100 million of 'anticipated royalties' (Ecuador Inmediato 2015), the majority of which has been invested in a series of public works in the region of El Pangui, including roads, a hospital, and three 'Millennium Schools' - emblematic educational complexes being constructed across the country. The decision to locate Ikiam's southern campus in El Pangui was also made in this context, and a promotional billboard for Ikiam was erected on the side of the highway into the town, emblazoned with a photograph of a huge green insect and the Ikiam slogan: 'Our Future Is Our Biodiversity. ${ }^{36}$ The billboard was still standing when we arrived in El Pangui over three years later. In the absence of the campus, the billboard symbolized the reduction of bio-socialism to "a phantasmatic screen, prohibiting us from confronting the true terrors of ecological catastrophe" (Adams 2010: 7). As we turned onto the road to the Mirador mine, however, this fantasy was replaced by "an insight into

\footnotetext{
${ }^{36}$ The information presented in this section draws on interviews with local politicians, government functionaries, and activists involved in the anti-mining movement.
} 
the forbidden domain, into a space that should be left unseen" (Žižek 1989: 71). Hillsides were being torn down to widen the road, and a constant stream of trucks thundered past us in a cloud of red dust. The river was being dredged for sand, and a gravel factory stood beside a newly constructed brothel on the river bank. Just upstream from the brothel we passed the home of the anti-mining activist, Jose Tendetza. His body was dragged from the river in 2014 at the height of the resistance to the mine, and two ECSA employees have been charged with his murder. ${ }^{37}$ Further up the road, we rounded a curve in the valley and the mine itself came into view. Deep red gouges had been cut into the lower slopes of an emerald green mountain. Along the road and high upon the hillsides, dozens of identical orange signs had been erected reading 'Private Property'. Crossing the river, we drove out across a long, broad plain that had been stripped of trees in preparation for the construction of the tailings reservoir. This had been the site of the impoverished community of San Marcos, until the $30^{\text {th }}$ of September 2015, when the Ecuadorian police collaborated with ECSA in the dismantling of the town and the displacement of its population. When we arrived at San Marcos in early December 2015 , only a few scattered homes remained, which were demolished a few days after our departure. Bio-socialism had finally completed its ideological inversion: the destruction of sumak kawsay and 'the rights of nature', in the name of the 'finite resources' of copper and gold. ${ }^{38}$

\section{Conclusion}

Bio-socialism was conceived as a radical agenda for the post-neoliberal production of nature, which sought to transcend Ecuador's economic dependence on the primary resources of the Amazon,

\footnotetext{
${ }^{37}$ The two accused men were recently found innocent, but the district attorney has since appealed the case, which remains unresolved as of January, 2017 (http://www.fiscalia.gob.ec/index.php/sala-de-prensa/4748fiscalía-apelará-la-sentencia-en-el-caso-del-asesinato-del-dirigente-shuar-josé-tendetza.html, last accessed 09/01/2017). When interviewed in December 2015, members of Tendetza's family insisted that ECSA had been involved in his murder, a view shared by the activists we spoke to. The company, however, has strongly denied any involvement in the affair. See Collyns 2016 and Sacher et al 2015 for further information.

${ }^{38}$ The information in this section is compiled from interviews with several ex-inhabitants of San Marcos and members of the Amazonian Community of the Cordillera del Condor (CASCOMI) (See also Sacher et al 2015). The Ecuadorian government disputes the version of event provided by CASCOMI, claiming that much of the land had been illegally invaded, that the displacements were peaceful and respectful of human rights, and that the displaced families have been compensated and rehoused elsewhere (Interview with Diego Fernando Esparza, Governor of Zamora-Chinchipe, 11/12/2015. See also ARCOM 2015).
} 
through engineering a transition to an economy based on biodiversity and scientific knowledge. In contrast to the commodification of nature and the destruction of indigenous cultures that had characterised the neoliberal era, bio-socialism was to be based on non-commodified public goods, the vindication of the indigenous concept of sumak kawsay, and the constitutional codification of the rights of nature. Yet through the process of its formalization and implementation, bio-socialism has come to reproduce the accumulation regime that it was designed to transcend, based on the expansion of the primary resource frontier and the opening of new fields of rentier capitalism. ${ }^{39}$ Such paradoxical inversions are the fate of utopian ideologies that become entangled with the material dynamics that they are structured to deny. As an ideological formation, bio-socialism combines an explicit anti-capitalist discourse with an implicit commitment to systemic competitiveness. The gap between these inconsistent elements has been papered over by the invocation of a harmonious external nature in opposition to 'extractivism'. Combined with a rejection of Marxian value theory, this has allowed the transition from the formal to the real subsumption of nature to be represented as a defence of the rights of nature itself.

This ideological formation has collided with Ecuador's historical location within the structures of global capitalism, which is based on the ground rent appropriated through the establishment of monopoly control over the natural resources required for the production of surplus value elsewhere. This material reality imposes severe constraints on any accumulation strategy that seeks to escape from the formal subsumption of nature to capital, to the extent that the expansion of the primary resource frontier in 'resource-rich' regions of the world is a necessary condition for processes of real

\footnotetext{
39 Data from the Bank of Ecuador demonstrates that the transformation of the productive matrix has not taken place, and that there is no significant trend in this direction. Ecuadorian exports remain dominated by oil and other primary commodities (principally bananas, cacao, shrimp and cut flowers). Non-primary exports continue to consist largely of petrochemicals, and have shown no overall increase over the course of the Citizens' Revolution (2007-2015). The figures for biotechnology are contained within the broader category of 'chemicals and pharmacy', which registered exports of US\$170 million in 2015, amounting to 0.93 percent of total Ecuadorian exports, a figure almost unchanged from 0.77 percent in 2007 . These figures are available at https://contenido.bce.fin.ec/home1/estadisticas/bolmensual/IEMensual.jsp
} 
subsumption underway in the global centres of industry. As we have seen, Ecuador is unable to compete in the international biotechnology sector. Far from catalysing a transition from the formal to the real subsumption of nature, Ikiam is instead functioning to open a new frontier of formal subsumption, through the appropriation of monopoly rents based on the unique biodiversity and 'ancestral knowledge' of the Amazon. Yet this project has failed to generate the rents required to sustain Ecuadorian capitalism, and the only immediate basis for expanded accumulation has proven to be the opening of the oil and mineral frontiers to intensified exploitation by transnational capital. This process is undermining the 'infinite resources' on which bio-socialism is supposed to be constructed, in order to fuel processes of real subsumption in the world centres of surplus value production - primarily China. The case of bio-socialism thus illustrates the inability of state policies to determine "the course of accumulation within each national space of valorisation. Instead, those nationally-differentiated political forms mediate the unfolding... of the contradictory dynamics of the total social capital at the global scale" (Grinberg and Starosta 2015: 240).

Ikiam was made possible by one of the surges of ground rent that have periodically enervated Latin American capitalism, but which have simultaneously functioned as a material obstacle to the real subsumption of labour to capital in the region, to the extent that "Latin American capital [has] continued to find it more profitable to valorise on the basis of the appropriation of a portion of ground-rent" (Grinberg and Starosta 2009: 773). At the level of ideology, these extraordinary flows of rent have enabled the production of the symbols of modernity in abstraction from their material foundation in the production of value (Echeverria 2011). Ikiam has staged a fantasy of modern biotechnology in the depths of the jungle, which was miraculously brought into existence by the magic of petrodollars. However, as Coronil has pointed out, the "Faustian exchange of oil for the illusion of progress" does not "bring the capacity to produce but the illusion of production" (Coronil 1997: 391). The collapse of the oil price has signalled the abrupt disappearance of the obscure forces sustaining this illusion. As the dream disintegrates, Ikiam is revealed as a 'living laboratory' without laboratories. Its secondary campuses have been abandoned; the Amazon continues to be pillaged 
for the resources required by global capital; and the indigenous and mestizo peasants of the region continue to struggle against their dispossession at the hands of the state. A Shuar leader living near the Mirador copper mine described this outcome as follows:

\begin{abstract}
"All the governments [of Ecuador] have devastated the country to satisfy their own economic interests and those of the transnationals. Because that's what it's all about. They don't consider the social, the human... still less the wildlife that exists in this country. But the current administration is in my opinion the worst that we have ever had... Because it has finished with everything... That is the road they are on, with their pretext of speaking of socialism, of a change that they don't understand." 40
\end{abstract}

The farcical involution of bio-socialism embodies the tendency for utopian ideological formations to reproduce the material realities that they are simultaneously obscuring and attempting to escape. As Susan Buck-Morss has argued, "Socialism necessitates a totally new relationship to nature. The technology of capitalism will not do to realize its aims" (Buck-Morss: 2002: 118). Bio-socialism promised to create a new relationship of precisely this kind. But it has taken the form of a fantasy based on the rent-financed mimesis of capitalist technology itself, in abstraction from the global dynamics of the subsumption of nature to capital. These dynamics have undermined the project, condemning it to failure, and confronting it with the truth that it was structured to conceal: "Capitalism does not have an ecological regime, it is an ecological regime" (Moore 2015: 158). ${ }^{41}$

\title{
References
}

Adams, Ross (2010) “Longing for a Greener Present: Neoliberalism and the Eco-City" Radical Philosophy 163 pp.2-7

Alianza País (2006) Plan de Gobierno del Movimiento PAIS 2007-2011 Quito: Alianza País ANDES (2012) “La minera Ecuacorriente paga los primeros USD 40 millones de regalías al Estado ecuatoriano"

\footnotetext{
40 Julio Tiwira, Shuar leader. Interview 09/12/2015, Gualaquiza, Ecuador. Mining projects have since led to further instances of dispossession and resistance in the region. As we make the final revisions to this article in January 2017, the province of Morona-Santiago in the southern Ecuadorian Amazon remains under a state of emergency, following the death of a policeman in December 2016, during clashes between Ecuadorian security services and members of the Shuar population at the site of another Chinese-owned mine in Panantza-San Carlos (Hill 2017).

${ }^{41}$ In July 2016, Rafael Correa announced that US\$15 million had been secured for the construction of the laboratories at Ikiam, and the rector of Ikiam has also recently been replaced. It remains to be seen whether these changes will alter the form or content of the project. However, as of January 2017, the construction of the new laboratories had yet to begin...
} 
Apter, Andrew (2005) The Pan-African Nation: Oil and the Spectacle of Culture in Nigeria Chicago: University of Chicago Press

ARCOM (2015) "Cerca de dos millones de dólares para 14 procesos de servidumbre en el proyecto Mirador" 17/12/2015 available at http://www.controlminero.gob.ec/?p=3226 (accessed 01/03/2016)

Arsel, Murat (2012) "Between Marx and Markets? The State, the 'Left Turn' and Nature in Ecuador" Tijdschrift voor Economische en Sociale Geografie 103:2 pp. 150-163

Arsel, Murat, Barbara Hogenboom, and Lorenzo Pellegrini (2016) "The Extractive Imperative in Latin America" The Extractive Industries and Society 3 pp. 880-887

Asemblea Constituyente (2008) Constitucion 2008 available at http://www.produccion.gob.ec/wpcontent/uploads/downloads/2012/07/Normas Constitucionales.pdf (accessed 13/01/2017)

Becker, Marc (2011) iPachakutik! Indigenous Movements and Electoral Politics in Ecuador Plymouth: Rowman and Littlefield

Becker, Marc (2012) "Building a Plurinational Ecuador: Complications and Contradictions" Socialism and Democracy 26:3 pp. 72-92

Becker, Marc (2013a) “Ecuador's Buen Vivir Socialism” in Roger Burbach, Michael Fox and Federico Fuentes. 2013. Latin America's Turbulent Transitions: The Future of Twenty-First Century Socialism London: Zed pp. 98-113

Becker, Marc (2013b) "The Stormy Relations between Rafael Correa and Social Movements in Ecuador" Latin American Perspectives 40 pp. 43-62

Billo, Emily (2015) "Sovereignty and Subterranean Resources: An Institutional Ethnography of Repsol's Corporate Social Responsibility Programs in Ecuador" Geoforum 59 pp. 268-277

Birch, Kean, Les Levidow and Theo Papaioannou (2010) "Sustainable Capital? The Neoliberalization of Nature and Knowledge in the European "Knowledge-Based Bio-economy'” Sustainability 2 pp. 2898-2918

Boelens, Rutgerd, Jaime Hoogesteger and Michiel Baud (2015) "Water reform governmentality in Ecuador: Neoliberalism, centralization, and the restraining of polycentric authority and community rule-making" Geoforum 64 pp. 281-291

Boyd, William, Scott Prudham and Rachel Schurman (2008). "Industrial Dynamics and the Problem of Nature" draft manuscript. Available at http://geography.utoronto.ca/wpcontent/uploads/2013/10/SNR2001final.pdf (accessed 11/12/2014)

Bridge, Gavin and Philippe Le Billon (2013) Oil Cambridge: Polity

Brush, Stephen B. (1993) "Indigenous Knowledge of Biological Resources and Intellectual Property Rights: The Role of Anthropology" American Anthropologist 95:3 pp. 653-671

Buck-Morss, Susan (2002) Dreamworld and Catastrophe: The Passing of Mass Utopia in East and West Cambridge: MIT Press

Burbach, Roger, Michael Fox and Federico Fuentes (eds.) (2013) Latin America's Turbulent Transitions: The Future of Twenty-First Century Socialism London: Zed

Burchardt, Hans-Jurgen and Kristina Dietz (2014) "(Neo-)extractivism - a new challenge for development theory in Latin America?" Third World Quarterly 35:3 pp. 468-486

Castaneda, Jorge (2006) "Latin America's Left Turn" Foreign Policy May/June

Chávez, David (2016) "Marx y el extractivismo" Revista Economia 67: 105 pp. 15-27

Collyns, Dan (2015) "Was this indigenous leader killed because he fought to save Ecuador's land?" The Guardian 02/06/2015 available at http://www.theguardian.com/world/2015/jun/02/ecuador-murderjose-tendetza-el-mirador-mine-project (accessed 29/02/2016)

Coronil, Fernando (1997) The Magical State: Nature, Money and Modernity in Venezuela Chicago: University of Chicago Press

Correa, Rafael (2002) "Reformas estructurales y crecimiento en América Latina: un análisis de sensibilidad" Revista le la CEPAL 76 pp. 89-107

Correa, Rafael (2014) “Ecuador y sus transformaciones en política, ciencia y tecnología” keynote speech delivered at the University of Yale, 10/04/2014

Davidov, Veronica (2013) “Mining versus Oil Extraction: Divergent and Differentiated Environmental Subjectivities in 'Post-Neoliberal' Ecuador" The Journal of Latin American and Caribbean Anthropology 18:3 pp. 485-504

De Vries, Pieter (2007) “Don't compromise your desire for development! A Lacanian/Deleuzian rethinking of the anti-politics machine" Third World Quarterly 28: 1 pp. 25-43

Eagleton, Terry (2007) Ideology: An Introduction London: Verso

Echeverría, Bolívar (2011) "Potemkin Republics: Reflections on Latin America's Bicentenary" New Left Review 70 pp. 53-61 
ECLAC (2012) Cambio Estructural para la lgualdad: Una visión integrada del desarrollo Santiago: ECLAC

Ecuador Inmediato (2015) “Ecuacorrientes ha estregado \$US70 millones por concepto de regalías anticipadas del proyecto Mirador" Ecuador Inmediato 03/08/2015 available at

http://ecuadorinmediato.com/index.php?module=Noticias\&func=news user view\&id=2818785932\&u $\underline{\mathrm{mt}=e c u a c o r r i e n t e s}$ ha entregado usd70 millones por concepto regalias anticipadas del proyecto mirador (accessed 01/03/2016)

El Comercio (2012a) "Resumen del enlace ciudadano No. 286" El Comercio 25/08/2012 available at http://www.elcomercio.com/actualidad/politica/resumen-del-enlace-ciudadano-no-6.html (accessed 29/02/2016)

El Comercio (2012b) “Enlace ciudadano No. 295 transmitido desde Tena" El Comercio 28/10/2012 available at http://www.elcomercio.com/actualidad/politica/enlace-ciudadano-no-295-transmitido.html (accessed 01/03/2016)

El Comercio (2014a) "La Universidad Ikiam conjuga la naturaleza con lo contemporáneo" El Comercio 18/01/2014 available at: http://www.elcomercio.com/actualidad/universidad-ikiam-conjuganaturaleza-contemporaneo.html (accessed 13/12/2014)

El Comercio (2014b) "Ikiam fusiona construcción ancestral y tecnología” El Comercio 01/02/2014 available at: http://www.elcomercio.com.ec/tendencias/construir/ikiam-fusiona-construccion-ancestral-y.html (accessed 13/12/2014)

El Comercio (2014c) “Otra actor entra el mercado de papel higiénico" El Comercio 18/10/2014 available at http://www.elcomercio.com/actualidad/empresa-mercado-papel-higienico-ecuador.html (accessed 13/01/2017)

El Telégrafo (2014) “Ávila: Ikiam no tendrá facultades” El Telégrafo 25/06/2014 available at: http://www.telegrafo.com.ec/sociedad/item/avila-ikiam-no-tendra- El Telégrafo. facultades.html (accessed 13/12/2014)

Ellner, Steve (2012) "The Distinguishing Features of Latin America's New Left in Power: The Chávez, Morales and Correa Governments" Latin American Perspectives 39 pp. 96-114

Elwood, Sarah et al (2016) "Learning from Postneoliberalisms" Progress in Human Geography (available on Early View).

Escribano, Gonzalo (2013) “Ecuador's energy policy mix: development versus conservation and nationalism with Chinese loans" Energy Policy 57 pp. 152-159

Fletcher, R, J Breitling and V Puleo (2014) "Barbarian Hordes: The Overpopulation Scapegoat in International Development Discourse" Third World Quarterly 35:7 pp. 1195-1215

Grinberg, Nicolas and Guido Starosta (2009) "The Limits of Studies in Comparative Development of East Asia and Latin America: The Case of Land Reform and Agrarian Policies" Third World Quarterly 30:4 pp. 761777

Grinberg, Nicolas and Guido Starosta (2015) "From Global Capitalism to Varieties of Centre-Leftism in South America: The Cases of Brazil and Argentina" in Susan J. Spronk and Jeffrey Webber (eds.) Crisis and Contradiction: Marxist Perspectives on Latin America in the Global Political Economy Leiden: Brill pp. 236-273

Grugel, Jean and Pía Riggirozzi (2012) “Post-neoliberalism in Latin America: Rebuilding and Reclaiming the State after Crisis" Development and Change 43:1 pp. 1-21

Gudynas, Eduardo (2011) “Buen Vivir: Today's Tomorrow” Development 54:4 pp. 441-447

Gudynas, Eduardo (2012) "Estado compensador y nuevos extractivismos: las ambivalencias del progresismo sudamericano" Nueva Sociedad 237 pp. 128-146

Harvey, David (2000) Spaces of Hope Berkeley: University of California Press

Harvey, David (2014) Seventeen Contradictions and the End of Capitalism London: Profile

Hill, David (2017) “Ecuador's Leading Environmental Group Fights to Stop Forced Closure" The Guardian 07/01/2017 available at https://www.theguardian.com/environment/andes-to-theamazon/2017/jan/07/ecuadors-leading-environmental-group-fights-forced-closure (accessed 09/01/2017)

Howard, Rosaleen (2002) "Yachay: The Tragedia del fin de Atahuallpa: Evidence of the Colonization of Knowledge in the Andes" in Henry Stobart and Rosaleen Howard eds. Knowledge and Learning in the Andes: Ethnographic Perspectives Liverpool: Liverpool University Press pp. 17-39

Ikiam (2016) "Talleres de investigación y acción participativa se realiza en comunidades del Napo" Ayllupura 2 Quito: SENESCYT pp. 6 
Iturralde, Pablo (2013) "Apuntes para Pensar la Ampliación de la Frontera Petrolera y Minera en Ecuador" in CDES, La Alquimia de la Riqueza: Estado, Petróleo, y Patrón de Acumulación en Ecuador Quito: CDES pp. 139-176

Kapoor, Ilan (2014) "Psychoanalysis and Development: Contributions, Examples, Limits" Third World Quarterly 35:7 pp. 1120-1143

Kapuscinski, Ryszard (2006) Shah of Shahs London: Penguin

Kaup, Brent (2014) "Divergent Paths of Counter-Neoliberalization: Materiality and the Labor Process in Bolivia's Natural Resource Sectors" Environment and Planning A 46:8 pp. 1836-1851

Kennemore, Amy and Gregory Weeks (2011) "Twenty-first Century Socialism? The Elusive Search for a PostNeoliberal Development Model in Bolivia and Ecuador" Bulletin of Latin American Research 30:3 pp. 267-281

Kimerling, Judith S. (1991) Amazon Crude New York: Natural Resources Defence Council

Labban, Mazen (2014) "Deterritorializing Extraction: Bioaccumulation and the Planetary Mine" Annals of the Association of American Geographers 104: 3 pp. 560-576

Larkin, Brian (2013) "The Politics and Poetics of Infrastructure" Annual Review of Anthropology 42:3 pp. 327343

Latorre, Sara, Katherine N. Farrell and Joan Martínez-Alier (2015) “The commodification of nature and socioenvironmental resistance in Ecuador: an inventory of accumulation by dispossession cases, 1980-2013" Ecological Economics 116 pp. 58-69

Leiva, Fernando Ignacio (2008a) Latin American Neostructuralism: The Contradictions of Post-Neoliberal Development Minneapolis: University of Minnesota Press

Leiva, Fernando Ignacio (2008b) "Towards a Critique of Latin American Neostructuralism" Latin American Politics and Society 50:4 pp. 1-25

Macias Vazquez, A. and P. Alonso Gonzalez (2016) “Between ‘neodevelopmentalism’ and 'postdevelopmentalism': towards a theory of a dispersed knowledge economy in Ecuador" Canadian Journal of Development Studies 37:1 pp. 47-65

Marx, Karl (1976) Capital Volume One New York: Random House

Moore, Jason W. (2011) "Ecology, Capital, and the Nature of Our Times: Accumulation and Crisis in the Capitalist World Ecology" American Sociological Association XVII:1 pp. 107-146

Moore, Jason W. (2015) Capitalism in the Web of Life: Ecology and the Accumulation of Capital London: Verso

Pellizoni, Luigi (2011) "Governing through disorder: neoliberal environmental governance and social theory" Global Environmental Change 21 pp. 795-803

Perreault, Tom (2012) "Dispossession by Accumulation? Mining, Water and the Nature of Enclosure on the Bolivian Altiplano" Antipode 45:5 pp. 1050-1069

Perreault, Tom and Gabriela Valdivia (2010) “Hydrocarbons, popular protest and national imaginaries: Ecuador and Bolivia in comparative context" Geoforum 41 pp. 689-699

Purcell, Thomas F., Nora Fernández and Estefanía Martínez (2016) “Rents, Knowledge and Neostructuralism: Transforming the Productive Matrix in Ecuador" Third World Quarterly (available on Early View)

Ramírez, René (2012) Socialismo del sumak kawsay o bio-socialismo republicano Quito: SENESCYT

Ramírez, René (2015a) “La disputa política por el sentido del (bio)conocimiento" keynote speech delivered at the conference Redes de bioconocimiento: una alternativa para el desarrollo FLACSO-Ecuador, Quito, $07 / 05 / 2015$

Ramírez, René (2015b) “Otra ética para otra sociedad: la de sumak kawsay" in Alfredo Serrano Mancilla (ed.) La nueva economía en la nueva constitución del Ecuador Quito: Servicio de Rentas Internas pp. 35-72

Ramírez, René (2015c) “Mas allá del marxismo y del capitalismo: más allá del 'valor de uso' y 'valor de cambio'” El Telégrafo 23/10/2015 http://www.eltelegrafo.com.ec/noticias/politica/1/mas-alla-delmarxismo-y-del-capitalismo-mas-alla-del-valor-de-uso-y-del-valor-de-cambio (accessed 29/02/2016)

Radcliffe, Sarah A. (2012) "Development for a post-neoliberal era? Sumak kawsay, living well and the limits to decolonisation in Ecuador" Geoforum 43 pp. 240-249

Rival Laura, Roldan Muradian and Carlos Larrea (2015) "New Trends Confronting Old Structures or Old Threats Frustrating New Hopes? ECLAC's Compacts for Equity" Development and Change 46:4 pp. 961-978

Rosales, Antulio (2013) “Going Underground: the political economy of the 'left turn' in South America" Third World Quarterly 34:8 pp. 1443-1457

Ruiz, Miguel. (2013). "Parte I", in CDES, La Alquimia de la Riqueza: Estado, Petróleo, y Patrón de Acumulación en Ecuador Quito: CDES pp. 1-68

Russotto, Margara (2013) "Research interview: rethinking Amazonia and its discourses. An interview with Ana Pizarro" Canadian Journal of Latin American and Caribbean Studies 38:1 pp. 123-138 
Sacher, William et al (2015) Entretelones de la megamineria en el Ecuador Quito: Acción Ecológica

Sawyer, Suzana (2004) Crude Chronicles: Indigenous Politics, Multinational Oll and Neoliberalism in Ecuador Durham: Duke University Press

http://unsdsn.org/news/2015/05/15/ecuadors-galapagos-islands-to-host-international-conference-on-

sustainable-development/ (accessed 01/03/2016)

SENESCYT (2013) Yachay: City of Knowledge Quito: SENESCYT

SENPLADES (2009) Plan Nacional Para el Buen Vivir 2009-2013 versión resumida Quito: SENPLADES

SENPLADES (2013) Buen Vivir: Plan Nacional 2013-2017 versión resumida Quito: SENPLADES

Smith, Anthony (1990) Explorers of the Amazon London: University of Chicago Press

Smith, Neil (2007) "Nature as Accumulation Strategy" available at http://3to1z93m5aspz1tlz1zcsjta2m.wpengine.netdna-cdn.com/goldstein2014/wpcontent/uploads/sites/316/2014/08/nature-as-accumulation-strategy.pdf (accessed 11/12/2014)

Starosta, Guido (2015) Marx's Capital, Method and Revolutionary Subjectivity Leiden: Brill

Swyngedouw, Erik (2010a) "Trouble with Nature" Ecology as the New Opium of the Masses" in Jean Healy and Patsy Hiller (eds.) in The Ashgate Research Companion to Planning Theory: Conceptual Challenges for Spatial Planning Farnham: Ashgate pp. 299-318

Swyngedouw, Erik (2010b) "Apocalypse Forever? Post-Political Populism and the Spectre of Climate Change" Theory Culture Society 27 pp. 213-232

Vallas, Steven Peter and Daniel Lee Kleinman (2008) "Contradiction, convergence and the knowledge economy: the confluence of academic and commercial biotechnology" Socio-Economic Review 6 pp. 283-311

Veltmeyer, Henry and James Petras (2014) The New Extractivism: A Post-Neoliberal Development Model or Imperialism for the Twenty-First Century? London: Zed

Villavicencio, Arturo (2014) Innovación, matriz productiva y universidad: por qué Yachay es una estrategia equivocada Quito: Fundación Hernán Malo

Watts, Michael (1994) "Petro-Violence: Community, Extraction and Political Ecology of a Mythic Commodity" in Nancy Lee Peluso and Michael Watts (eds.) Violent Environments Ithaca: Cornell University Press pp. $189-212$

Webber, Jeffrey (2016) "Evo Morales and the political economy of passive revolution in Bolivia, 2006-15" Third World Quarterly 37:10 pp.1855-1876(2016)

Wilson, Japhy (2014) "The Shock of the Real: The Neoliberal Neurosis in the Life and Times of Jeffrey Sachs", Antipode: A Radical Journal of Geography 46:1 pp. 301-321

Wilson, Japhy (2016) "The Village that Turned to Gold: A Parable of Philanthrocapitalism" Development and Change 47:1 pp. 3-28

Wilson, Japhy (2017) "Perplexing Entanglements with a Post-Neoliberal State" Journal of Latin American Geography 16:1 (forthcoming)

Wilson, Japhy and Manuel Bayón (2016) “Black Hole Capitalism: Utopian Dimensions of Planetary Urbanization" City: Analysis of Urban Trends, Culture, Theory, Policy, Action 20:3 pp. 250-267

Wilson, Japhy and Manuel Bayón (2015) "Concrete Jungle: The Planetary Urbanization of the Ecuadorian Amazon" Human Geography 8:3 pp. 1-23

Wylie, Lesley (2014) "Introduction to Special Issue on Amazonian Literatures" Hispanic Issues Online 16 pp. 116

Yates, Julian S. and Karen Bakker (2014) "Debating the 'post-neoliberal turn' in Latin America" Progress in Human Geography 38:1 pp. 62-91

Zeller, Christian (2008) "From the Gene to the Globe: Extracting Rents based on Intellectual Property" Review of International Political Economy 15:1 pp. 86-115

Žižek, Slavoj (1989) The Sublime Object of Ideology London: Verso

Žižek, Slavoj (1992) Looking Awry: An Introduction to Jacques Lacan through Popular Culture Cambridge: MIT Press

Žižek, Slavoj (1997) The Plague of Fantasies London: Verso

Žižek, Slavoj (2008) Violence London: Profile

Zucker, Lynne G., Michael R. Darby and Jeff S. Armstrong (2002) "Commercializing Knowledge: University Science, Knowledge Capture, and Firm Performance in Biotechnology" Management Science 48:1 pp. $138-153$ 